\title{
TERRITORIALITY, PUBLIC POLICY AND THE CONFLICT OF LAWS
}

Ernest G. Lorenzen

Dicey calls attention to the fact that there are two great schools of writers on the Conflict of Laws - the theoretical and the positive. The theoretical writers attempt to deduce the rules of the Conflict of Laws from some $a$ priori principle. Starting with some general principle, they try to derive therefrom a body of consistent rules. The positive method, on the other hand, studies the actual rules in force and attempts to reduce them to systematic order. The theoretical method is adopted by the great majority of continental writers, whereas the positive method is preeminently that of the English and American writers. Concerning the advantages and disadvantages of the theoretical method Dicey says : ${ }^{1}$

"The advantages of the theoretical mode of treatment, when employed by a man of genius, such as Savigny, are in danger of being underrated by English lawyers, to whose whole conception of law it is at bottom opposed. It is therefore a duty to bring these merits into prominence. The two great merits of the method are, first, that it keeps before the minds of students the agreement between the different countries of Europe as to the principles to be adopted for the choice of law, and next that it directs notice to the consideration which English lawyers are apt to forget; that the choice of one system of law rather than of another for the decision of a particular case is dictated by reasons of logic, of convenience, or of justice, and is not a matter in any way of mere fancy or precedent. Whether, for example, the legal effect of a given transaction ought to be tested by the lex actus, the lex domicilit, or the lex fori, is a matter admitting of discussion, and which ought to be discussed on intelligible grounds of principle. . . .

"The true charge against the theoretical method is that it leads the writers who adopt it to treat as being law what they think ought to be law, and to lay down for the guidance of the courts of every country rules which are not recognized as law in any country whatever. 'The - jurists of continental Europe,' writes Story, 'have, with uncommon skill and acuteness, endeavored to collect principles which ought to regulate this subject among all nations. But it is very questionable whether their success has been at all proportionate to their labour. and whether their principles, if universally adopted, would be found either convenient or desirable, or even just, under all circumstances.' This remark exactly hits the weak point of a method which rests on the assumption, common to most German jurists, but hardly to be admitted by an English lawyer, that there exist certain self-evident principles of right whence can be deduced a system of legal rules, the rightness of which will necessarily approve itself to all competent judges."

Anglo-American writers, being positivists, attempt to state only the rules laid down by the English and American courts and they do not claim universal validity for these rules. English writers in particular

'Dicey, Conflict of Laws (3d ed. r922) I8-r9. 
have been careful not to indulge in any generalizations not warranted by the decisions. There are certain statements in Story, on the other hand, which might suggest that the Anglo-American rules of the Conflict of Laws have been established as the direct result of the principle of the territoriality of law.

Says Story:

"Before entering upon any examination of the various heads, which a treatise upon the Conflict of Laws will naturally embrace, it seems necessary to advert to a few general maxims or axioms which constitute the basis upon which all reasonings on the subject must necessarily rest; and without the express or tacit admission of which it will be found impossible to arrive at any principles to govern the conduct of nations, or to regulate the due administration of justice."”

"The first and most important general maxim or proposition is that which has been already adverted to, that every nation possesses an exclusive sovereignty and jurisdiction within its own territory. The direct consequence of this rule is, that the laws of every state affect and bind directly all property, whether real or personal, within its territory, and all persons who are resident within it, whether naturalborn subjects or aliens, and also all contracts made and acts done within it."3

"Another maxim or proposition is, that no state or nation can by its laws directly affect or bind property out of its own territory, or bindpersons not resident therein, whether they are natural-born subjects or others. This is a natural consequence of the first proposition; for it would be wholly incompatible with the equality and exclusiveness of the sovereignty of all nations, that any one nation should be at liberty to regulate either persons or things not within its territory." "4

"Upon this rule there is often ingrafted an exception of some importance to be rightfully understood. It is that although the laws of a nation have no direct binding force or effect, except upon persons within its own territories, yet that every nation has a right to bind its own subjects by its own laws in every other place."

Compared with the continental systems, it is manifest that the AngloAmerican rules of the Conflict of Laws give a much wider range to the application of the law of the situs as regards transactions affecting real property. ${ }^{6}$ The powers of executors and administrators, guardians and trustees in bankruptcy, according to Anglo-American law, do not extend on principle beyond the limits of the state in which they were appointed, whereas the contrary is true on the continent. ${ }^{7}$ The jurisdiction of courts in personal causes of action is predicated upon service of process within the state. ${ }^{8}$ In these and other respects the Anglo-American

'Story, Conflict of Laws (8th ed. 1883) sec. 17.

Ibid. sec. I8.

Ibid. sec. 20.

s Ibid. sec. 2 I.

- Concerning the continental law see Lorenzen, Cases on the Conflict of Laws (2d ed 1924) 506, note; 507, note.

${ }^{3}$ Lorenzen, op. cit. 903, note.

The continental and South American countries take a contrary view. Lorenzen, op. cit. I26-127, note. 
system of the Conflict of Laws may be characterized as more territorial in its nature than the continental. So far as Story's maxims express only this general attitude of the Anglo-American law no fault can be found with them. They cannot be approved, however, in so far as they suggest that the rules of the Conflict of Laws adopted by the English and American courts follow as a matter of logical and necessary deduction from the principle of the territoriality of law.

Directing the attention to the particular form in which the maxims are expressed by Story and the immediate consequences drawn therefrom, one cannot help but be impressed by the vagueness of their character. What does Story mean when he says that as a direct consequence of the exclusive sovereignty and jurisdiction which a state possesses within its own territory its laws affect and bind directly all property within its territory, persons resident therein, and acts done therein?

As regards real estate Anglo-American courts have gone far in applying the law of the situs. Conveyances of land are accordingly held to be governed by that law, both as to "capacity," "form," and "essential validity." This rule had been applied not only by the courts of the state in which the land is situated (state A), but also by the courts of any other state in which the common law point of view exists. That the above rule is not a necessary one, resulting directly from the "exclusive sovereignty and jurisdiction" of state A is seen, however, from the fact that since the time Story wrote a good many legislatures have enacted that deeds to land within their state shall be deemed sufficiently executed if they satisfy the form requirements of the

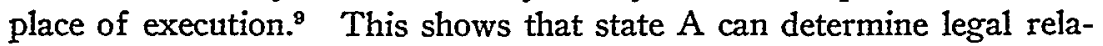
tions with reference to land lying with its territory by some other rule than the lex reis sitae. On the continent the law of the situs is not applied with reference to either "capacity" or "form."10

State A has, of course, no power to impose its own policy upon any other sovereign state. Only some supra-state authority could do this.

In its application to chattels, Story's first maxim does not give in the least an accurate picture of the rules of the Conflict of Laws prevailing at the time or now. The transfer of chattels was governed at the time Story wrote by the law of the situs neither as regards "capacity." "formalities," or "essential validity." Rights therein were governed as a rule by the law of the domicile of the owner. During the latter half of the last century a more controlling influence has been given by Anglo-American law to the law of the situs with respect to chattels than

'See Lorenzen, The Validity of Wills, Deeds and Contracts as Regards Form in the Conflict of Lazes (I9II) 20 YALE LAw Journar, 427, 433-434. See also In re De Nicols [1900] $2 \mathrm{Ch}$. Div. 410, where it is suggested that the law of matrimonial domicile may control the rights of husband and wife in English realty if the parties were domiciled at the time of their marriage in a state in which the community of property régime prevailed. Compare Dicey, op. cit. 555.

"Supra note 6 . 
theretofore, but only where the transfer was inter vivos, and did not result from the operation of law. ${ }^{11}$ The sovereign of the situs has declined also, on grounds of policy, to apply its local law in instances which cannot be explained on any theory of territoriality. ${ }^{12}$ To say that the law of the situs has "exclusive sovereignty and jurisdiction" with respect to chattels is, therefore, only a vague and meaningless statement, which does not express the existing law on this subject.

Story next asserts that state $A$ has "exclusive sovereignty and jurisdiction" over all persons who are resident within it. It is difficult to see how this is the direct consequence of the "exclusive sovereignty and jurisdiction" which state A possesses within its territory. One " would expect from such exclusive territorial jurisdiction that state $A$ would have power with respect to all persons physically within the state, and this is the actual law of England and the United States as regards the jurisdiction of courts in personal causes of action, service of process within state $A$ on any person found within the state having always been deemed sufficient by Anglo-American courts. ${ }^{13}$ When Story made the above statement he evidently had in mind what is often spoken of as "status." But why should the law of the residence or domicile of a person govern in this respect rather than some other law? No theory based upon the territoriality of law can give an answer to this question, for to say that domiciled persons are constructively within the territory is to make use of a fiction which confuses "territorial" and "personal" jurisdiction. Since the time Story wrote many of the continental countries, as well as Brazil, Japan, etc., have accepted the law of nationality in this regard. ${ }^{14}$ Whether the law of domicile, the law of nationality or some other law is adopted for the solution of the problems of the Conflict of Laws involving "status," depends again upon the policy of state $A$ and cannot be derived from any theory of territoriality.

Another direct consequence of his first maxim, according to Story, is that the laws of every state affect and bind directly all contracts made and acts done within the state. This statement can be true only so far as the courts of state $A$ are concerned, for state $A$ has no power to

II See Cammell v. Sewell (1860, Exch. Ch.) 5 Hurl. \& N. 728. Where the passing of "title" results directly from the operation of law, the lex donticilii is generally held to control. De Nicols v. Curlier [1900, H. I.] A. C. 2 I (matrimonial property); Saul v. His Creditors (I827, La.) 5 Mart. (N. s.) 569 (matrimonial property); Ennis v. Smith (1852, U. S.) I4 How. 400 (intestate succession).

${ }^{12}$ See Wray Bros. v. White Auto Co. (I922) I55 Ark. I53, 244 S. W. 18 (registration of chattel mortgage).

${ }^{13}$ Pennoyer v. Neff (1877) 95 U. S. 714; Fisher v. Fielding (1895) 67 Conn. 9I, 34 At1. 7I4. The continental law is opposed to this view. See Lorenzen, op. cit. supra note 6 , at pp. I26-I27, note.

"Lorenzen, op. cit. supra note 6, at p. 9, note; Art. 3 of Japanese Law Concerning the Application of Laus in General, De Becker, International Private Law of Japan (rgrg) 75. 
prescribe the Conflict of Laws rules for any other state. The application of its own local rules to contracts made within the state or wrongful acts done within its territory does not result, however, of necessity from the territoriality of 1aw, but from the policy of state A. ${ }^{15}$ Story himself maintains that state $A$ should apply the law of state $B$ to a contract made in state $\mathrm{A}$ and to be performed in state $\mathrm{B} \cdot{ }^{\mathbf{1 6}}$

Story's second maxim, which is said to be a corollary of the first, is that no state can by its laws directly affect or bind property out of its own territory or bind persons not resident therein. This maxim is even more misleading than the first. So far as B's courts are concerned, or the courts of another state, state A can of course not bind them in any way. It can lay down rules in the Conflict of Laws only for its own courts. But if $\mathrm{A}$ is a sovereign state, can it not provide that upon the death of the owner his property, including real estate in state $B$, shall pass to his heirs in accordance with the personal law of the deceased? Such a provision may be, of course, impolitic if the rule of the situs is not identical, but the question to be considered is merely whether state $B$ has exclusive jurisdiction in the sense that no other state can determine jural relations with respect to real property situated in state $B$ in accordance with some local law other than that of the situs. It would seem manifest that, unless forbidden by some supra-state authority, a sovereign state, A, has the power, so far as its owen courts are concerned, to determine all jural relations including those affecting real property in state $B$ as its own sense of justice and policy may suggest. ${ }^{17}$ Indeed, the Italian Civil Code has a specific provision that all property, including real estate in foreign countries, shall devolve in case of death in accordance with the law of the state or country to which the deceased belonged by nationality. ${ }^{18}$ It is true, of course, that if the land were situated in this country the Italian provision would have no effect so far as our courts are concerned, but if the matter comes before an Italian court, the rights of the heirs would be determined as if the property were Italian property.

No state has so far attempted to say that the "title" to foreign realty shall be determined under all circumstances, so far as its courts are concerned, by a rule other than that of the situs. The Italian courts have had sufficient difficulty with their limited rule, as regards succession

\footnotetext{
${ }^{15}$ Cook, The Logical and Legal Bases of the Conflict of Laws (1924) 33 YALE Law JournaI, $457,466 \mathrm{ff}$.

${ }^{10}$ Story, op. cit. supra note 2, at p. 376.

${ }^{17}$ See Cook, op. cit. supra note 15, at p. 457; (1918) 28 YALE LAW JourNaL, 67 ; Lorenzen, The Theory of Qualifications and the Conflict of Laws (1920) 20 Cox. L. Rev. 247, 265, $270 \mathrm{ff}$.

${ }^{18}$ Art. 8 of the Preliminary Dispositions of the Italian Civil Code expressly provides that the national law of the decedent shall govern testamentary and intestate succession, including movables and immovables wherever situated. See also Cass. Turin, Dec. 20, 1905 (35 Clunet, r9ro); hut compare Cass. Palermo, Aug. 25, I894 (Sirey, I895, 4, 28, note).
} 
upon death, to be a warning to other countries. The fact that the physical res is in state $B$ gives to state $B$ in the nature of things the exclusive power to control the physical possession and enjoyment of the real property within its territory. State $A$ has no such control and can acquire it only by making war upon $B$ and gaining control over the physical res. State A can create a local "title" to land in state B, but it would be a "title" which might not be recognized by state $B$ and without such recognition it would be worth little. Full ownership in land implies the possibility of the actual enjoyment of the physical res. On grounds of obvious expediency and common sense, it is held, therefore, practically universally that the "title" to land shall be determined in case of conflict with reference to the law of the situs. No such compelling grounds of convenience exist, however, so far as the law of the situs gives effect to a foreign rule contrary to its own local rule. On this principle courts of equity in England and the United States have declared rights with respect to foreign land in accordance with their own local rules and without reference to the rule of the situs. ${ }^{19}$ In these cases it is said that the "title" to the foreign law is affected only "indirectly," by virtue of the power of the court to compel the parties before them to execute the proper papers. In view, however, of the fact that the duty upon which the action of the court is predicated does not exist under the law of the situs, but is created by the law of the state where the action is brought, it is obvious that the law of the forum is allowed to change the legal relations with respect to foreign land. There is no supra-state rule that all rights with respect to foreign land must be determined under all circumstances in accordance with the law of the situs, and until such a rule is established each sovereign state must determine the matter in accordance with its own sense of what is convenient and just. $^{20}$ In this country complete freedom is not possessed, of course, by the individual states because of constitutional provisions.

So far as the second maxim relates to chattels it was inexact at the time Story wrote even as a matter of self-limitation on the part of state A. State $A$ as an independent sovereign could, of course, determine, so far as A's courts are concerned, legal relations with respect to chattels in state $B$, in accordance with some other law than that of state $B$, and the courts actually determined such rights in accordance with the law of the owner's domicile. ${ }^{21}$

With respect to persons, Story's second maxim would not allow state A to bind "persons not resident therein," except citizens of state

\footnotetext{
${ }^{10}$ Cranstozen v. Johnston (I796, Ch.) 3 Ves. I70; Ex parte Pollard (I840, Bankruptcy) Mont. \& C. 239; Burnley v. Stevenson (1873) 24 Ohio St. 474.

${ }^{30}$ International law does not limit the power of states in this respect. See Lorenzen, The Theory of Qualifications and the Conflict of Lazes, supra note 17 , at pp. $265,278 \mathrm{ff}$.

11 The notion that the law of the situs should control was introduced only in I866 through the case of Cammell v. Sewell, supra note II.
} 
A. Why Story should regard the power of state A to bind persons domiciled in state $A$ wherever they are as a consequence of the "exclusive sovereignty and jurisdiction" of state $A$ within its territory, and its power over citizens as an exception to the principle of territoriality, it is difficult to see. So far as state $A$ exercises jurisdiction over persons actually within another state, either because they are domiciled in state $A$, or because they are citizens of state $A$, it is clear that the jurisdiction is assumed because of a personal relationship between the party and state $A$. That state A may properly do so is generally, but not universally, admitted. ${ }^{22}$ Both grounds of jurisdiction would appear to be exceptions to Story's theory of territoriality.

-Although Story has omitted an express statement to that effect, it would seem to follow as a natural consequence from his first maxim that state $\mathrm{A}$ has no power to affect or bind contracts or other acts done in another state. But such a statement as this could mean only that as a matter of self-limitation state A would not exercise its power. If it saw fit state A could say that, so far as its courts are concerned, the local rule of state A should apply to all contracts wherever made and to all torts wherever committed. In fact some territorialists have advocated that the lex fori should always govern as regards foreign torts. ${ }^{23}$ Story's statement is not true even from the standpoint of self-limitation on the part of state A. Story himself does not adhere to the view that the law of the state where a contract was entered into governs its validity, for he expressly holds that where the place of performance is in another state, the law of the latter controls. ${ }^{24}$ And the English Court of Appeal has awarded damages for a tort, according to the rules of English law, although the wrongful act did not give rise to a private action in the state where it was committed, but only to a criminal prosecution. ${ }^{25}$ The weight of Anglo-American ${ }^{26}$ as well as of continental ${ }^{27}$ authority is opposed also to the view that the law of the place where a contract is made determines the validity of such contract. All of this goes to show that the application of the law of the place of the contract or act is not firmly nor uniformly established even in AngloAmerican law as a matter of self-limitation.

\footnotetext{
${ }^{22}$ In favor of such jurisdiction see Douglas v. Forrest (1828, C. P.) 4 Bing. 686; Henderson v. Staniford (1870) I05 Mass. 504; McDonald v. Mabee (I9I7) 243 U. S. 90, 37 Sup. Ct. 343. Contra: De la Montanya v. De la Montanya (1896) II2 Calif. IoI, 44 Pac. 345; Raher v. Raher (I9II) I50 Iowa, 5Ir, I29 N. W. 494.

${ }_{22}$ Wächter, Über die Kollision der Privatrechtsgesetze versschiedener Staaten (1842) 25 ARCHIV Für DIE crvilistische PRAXIs, $389 \mathrm{ff}$; Schmid, Die Herrschaft der Gesetze und deren raümlichen und zeitlichen Grenzen (1863) 76.

"Story, op. cit. supra note 2 , at p. 376.

${ }^{23}$ Machado v. Fontes [1897] 2 Q. B. 23T. .

${ }^{\infty}$ Beale, What Law Governs the Validity of a Contract (1909-10) 23 Harv. L. REv. 79, 194.

${ }^{27}$ Lorenzen, op. cit. supra note 6, at p. 339, note; Lorenzen, The Validity and Effects of Contracts in the Conflict of Laws (r921) 30 Yale Law Journar, 565,567 .
} 
A very simple case will bring into evidence the inadequacy of Story's maxims as a guide to the solution of the problems of the Conflict of Laws. Suppose that the question relates to the validity of a deed to land situated in state $A$, the deed being executed and delivered in state $\mathrm{B}$ by X, a citizen of state C. According to Story's first maxim state A has exclusive power over the property; state $B$ has exclusive power over the execution of the deed, the act being done in state $B$; and state $C$, exclusive power over $X$. How are we to get out of the embarrassment? By applying the law of state $A$ where the property is situated? But why should the laws of state $B$ and of state $C$ relinquish their power? Who is to be the umpire to choose from among the competing powers the one that is to control?

The only conclusion that can be reached from the foregoing discussion is that the rules of the Conflict of Laws are not based upon, nor are they derivable from, any uniform theory of territoriality. ${ }^{28}$ In one class of cases reference is had to the law of the situs of the property; in others to the law of the place where the act in question occurred. In still other cases the rights are determined neither with reference to the situs of the property, nor with reference to the law of the state where the act occurred, but with reference to the law of domicile. Whether the rule of the one state or of the other shall be chosen is not prescribed by any supra-state authority, nor can it be deduced from any a priori principle.

In view of the foregoing it is a little surprising to find among the American courts and writers of to-day a tendency to accept the doctrine of the territoriality of law as the major premise for the solution of the problems of the Conflict of Laws. How else can be explained statements like the following:

"If the law of the place where the parties act refuses legal validity to their acts, it is impossible to see on what principle some other law may nevertheless give their acts validity. The law of the place of performance can have no effect as law in another place, namely, the place where the parties act; for it is a fundamental doctrine of our law that 'the laws of every state affect and bind directly .... all contracts made, and acts done within it. A state may therefore regulate .... the validity of contracts and other acts done within it; the resulting rights and duties growing out of these contracts and acts.' Any attempt to make the law of the place of performance govern the act of contracting is an attempt to give to that law extraterritorial effect."'29

"In all these cases the matter must, it seems, be determined theoretically by the law governing the transaction, $i$. e., the law of the place where the parties act in making their agreement. If by that law their acts have no legal efficacy, then no other state can give them greater

${ }^{23}$ This becomes all the more apparent if we compare the conclusions of the different territorialists. See for example, Wächter, Über die Kollision der Privatrechtsgesetze verschiedener Staaten (I84I) 24 ARCHIV füR DIE CIVIISTISCHE PrAXIS, 230; (1842) 25 ARCHIV Für DIE crvIIISTISCHe PrAXIS, I5I, 36I; Schmid, op. cit. supra note 25; Vareilles-Sommières, La Synthèse du Droit International Privé ( 1897 ).

${ }^{20}$ Beale, What Law Governs the Validity of a Contract, supra note 26, at p. 267. 
effect. If by the law of that state their acts created a binding obligation upon the parties, then the parties who have acted under that law must be bound by it."30

"The question whether a contract is valid, that is, whether to the agreement of the parties the law has annexed an obligation to perform its terms, can on general principles be determined by no other law than that which applies to the acts, that is, by the law of the place of contracting. If the law at that place annexes an obligation to the acts of the parties, the promisee has a legal right which no other law has power to take away except as a result of new acts which change it. If on the other hand the law of the place where the agreement is made annexes no legal obligation to it, there is no other law which has power to do so.....

"This doctrine gives full scope to the territoriality of law, and enables each sovereign to regulate acts of agreement done in his own territory." ${ }^{31}$

As has been, shown above, the exclusive power to determine the legal consequences of operative facts can be assigned to a particular state only by some supra-state authority; it does not follow from the nature of sovereignty nor from any self-evident theory of territoriality. So far as the rule of the place where the contract is made (state $B$ ) is deemed to determine the validity of such contract it must necessarily be, in the absence of any supra-state authority imposing such rule, because the state in which the question arises (state $A$ ) has seen fit to select the rule of such state.

However disappointing the foregoing conclusion may be to those who believe that there ought to be as far as possible one body of rules govern-

${ }^{30}$ Ibid. 268.

"Ibid. 270-27I; see also Minor, Confict of Lavs (I90I) 4Io. Mr. Justice Holmes said in Slater $v$. Mexican National R. $R$. (I904) I94 U. S. 120, 126, 24 Sup. Ct. 581, 582, 583:

"As Texas has statutes which give an action for wrongfully causing death, of course there is no general objection of policy to enforcing such a liability there, although it arose in another jurisdiction. Stezart v. Baltimore \& Ohio $R . R$., I68 U. S. 445. But when such a liability is enforced in a jurisdiction foreign to the place of the wrongful act, obviously that does not mean that the act in any degree is subject to the lex fori, with regard to either its quality or its consequences. On the other hand, it equally little means that the law of the place of the act is operative outside its own territory. The theory of the foreign suit is that although the act complained of was subject to no law having force in the forum, it gave rise to an obligation, an obligatio, which, like other obligations, follows the person, and may be enforced wherever the person may be found. Stout $v$. Wood, $x$ Blackf. (Ind.) $7 \mathrm{I}$; Dennick v. Railroad Co., 'xO3 U. S. II, I8. But as the only source of this obligation is the law of the place of the act it follows that that law determines not merely the existence of the obligation, Smith v. Condry, I How. 28, but equally determines its extent. It seems to us unjust to allow a plaintiff to come here absolutely depending on the foreign law for the foundation of his case, and yet to deny the defendant the benefit of whatever limitations on his liability that law would impose."

Compare with the above statement by Mr. Justice Holmes the following from Judge Learned Hand in Guinness v. Miller (1923, S. D. N. Y.) 29r Fed. 769, 770: "However, no court can enforce any law but that of its own sovereign, and, when a suitor comes to a jurisdiction foreign to the place of the tort, he can only invoke an obligation recognized by that sovereign. A foreign sovereign under civilized law imposes an obligation of its own as nearly homologous as possible to that arising in the place where the tort occurs." 
ing the problems of the Conflict of Laws in all countries, or to those who believe that the domestic rules should be the expression of "fundamental principles," nothing can be gained by hiding the truth and making it appear that certain rules govern in the nature of things. Such rules have not been discovered by the theoretical writers of the greatest eminence, nor has a consistent set of rules been worked out as yet by either the English or the American courts. The common law has not hidden in its bosom a logical set of rules which can be derived from its notion of territoriality. Sound progress in this field of the law, as in all other departments of knowledge, can be made only if the actual facts be faced, which show that the adoption of the one rule or the other depends entirely upon considerations of policy which each sovereign state must determine for itself.

Should the contention be made that the passages quoted above are not a deduction from an $a$ priori principle, but merely the expression of what the common law courts have held on the subject, the answer must be that such contention does not rest upon fact. The English courts have not held that the validity of a contract shall be governed exclusively by the law of the place of contracting, nor have the American courts. It may be said without exaggeration that there is not a single state in this country which has uniformly and consistently subscribed to this doctrine. In the majority of the states it is rejected either in its entirety or it has received support only in particular instances or directions. Under the prevailing conditions the law of the place of contracting may be the better rule, or it may not be. The question is subject to argument, and the answer should not be foreclosed by any fictitious assumption regarding the existence of fixed general rules in the "common law."

What has been stated in the preceding paragraph applies to most questions in the Conflict of Laws. There are, relatively speaking, few rules of the Conflict of Laws which can be said to be recognized by all Anglo-American states, or by the great majority of them. To the extent that there is such agreement, we may speak of them as common rules; but to assert that there are general rules of the "common law," to be derived from its notion of territoriality, which have binding force regarding matters concerning which there is little or no authority, or as to which the decisions are in total disagreement, is to assert something that is untrue, for it presents as existing and binding law something which has for its support merely the personal opinion of the person making such assertion as to what he believes would constitute a sound rule, and so far as such conclusion rests upon a general theory concerning the nature of law rather than a careful weighing of the conflicting interests and policies involved, it constitutes reasoning from a fictitious major premise.

The charge to be made against this mode of dealing with the problems of the Conflict of Laws is the same as that made by Dicey concerning 
the theoretical method in general, namely, "that it leads the writers who adopt it to treat as being law what they think ought to be law." That the a priori method has not yielded sound and satisfactory results, although it has been employed by the most eminent jurists on the continent for many years, is admitted by a very distinguished writer, who says : ${ }^{32}$

"These imperfections (in the subject of the Conflict of Laws) do not result solely from the special character and complexity of the questions which Private International Law has for its object to resolve, but also from the defective method which has been used in its elaboration. The authors which have formulated its rules have almost always attempted to deduce them from a very general and very abstract notion: territorial sovereignty, personal sovereignty, community of law between states, international courtesy, or, what amounts to the same thing, mutual respect of one sovereign for another, maintenance of rights vested under the law of a foreign state, etc. The a priori principle, from which these authors have pretended to derive their theory, has always proved powerless to furnish or to justify a practical rule; on the contrary it has only too often misled such author in his search for a solution."

The notion that the rules of the Conflict of Laws can be derived from some general formula or theory is responsible for another doctrine - that of "public policy"-which in turn has caused the utmost confusion. Realizing that the logical deductions from their a priori theory could not be justified in all cases, the theoretical writers have allowed the ordinary rules, which govern "on principle," to be set aside under certain circumstances by the rules of "public policy" or "public order." Anglo-American courts and writers, as we have seen, ${ }^{33}$ also use language implying that the ordinary rules, governing "on principle," are the expression of the territoriality of law, as understood by Anglo-American countries. These also are allowed to be nullified on grounds of "public policy" by certain provisions of the law of the state in which the question arises. The foreign writers have tried their utmost to classify these provisions, and to clarify the doctrine of public policy, but without success. $^{34}$ The term is used in different senses according to the general point of view of the school to which the particular writer belongs or of the individual writer himself. Some use it in a comprehensive sense,

${ }^{32}$ Arminjon, Le Domaine du Droit International Privé (I922) 49 Clunet, 905.

${ }^{33}$ Supra notes 29-3r.

3s "No attempt to define the limits of that reservation (public policy) has ever succeeded, even to the extent of making its nature clearer than by saying that it exists in favor of any stringent domestic policy, and that it is for the law of each country, whether speaking by the mouth of its Legislature or by that of its judges, to determine what parts of its policy are stringent enough to require its being invoked." Westlake, Private International Law (6th ed. I922) 51. For the literature on the subject see Beale, Conflict of Lares (Igr6) 77,78 , note; also Fink, Die Prinzipien des Internationalen Privatrechts und die Vorbehaltsklansel (I9I4) 24 Zeitschrift für Internationales Recht, 138; Kosters, Public Policy in Private International Law (I920) 29 Yale LAW Journal, 745. 
so as to include what others regard as a special doctrine, namely, that of the evasion of law, or fraud upon the law..$^{35}$ Most frequently the doctrine of public policy is regarded as having merely a negative function, that of justifying the non-application of a "foreign" law, which ought to govern "on principle." Others assign to it also a positive function, according to which duties may be imposed contrary to those that would result from the application of the.general rule. In this view, which is at times shared by the courts, ${ }^{36}$ the doctrine of public policy is not merely a convenient safety-valve to prevent the application of "foreign" law, but a method whereby old rules are modified and new rules established. In England and the United States the doctrine of public policy is generally limited to its negative function, and no attempt has been made by the Anglo-American writers to reduce the cases falling within this doctrine to any system or order.

The doctrine of public policy in the Conflict of Laws ought to have been a warning that there was something the matter with the reasoning upon which the rules to which it is the exception were supposed to be based. Judge Beach has called attention to the illogical character of this doctrine as between the different states of this country ${ }^{37}$ and a similar charge may be made with respect to the application of this doctrine to foreign countries. If some power other than that of state A prescribes for A the rule that is to govern "on principle," if that rule is obligatory upon state $A$, how can state $A$ deny effect to such rule in a particular case? If state $A$ is bound to recognize the exclusive power of state $B$ to attach legal consequences to certain operative facts, how can the courts of state $A$ nullify the effect given to such operative facts by state $B$ ? If state $B$ had the power to create "vested rights," 38 so far as state $A$ is concerned, why should such rights not be entitled to recognition if called in question in state $A$ ? Is it not strange to argue in the first place that state $A$ has no choice in accepting the original rule and then to admit that it has the power to set aside the effect of that rule whenever it pleases on the plea that such recognition or enforcement would violate its public policy?

This situation has resulted from the fact that it has been deemed necessary to discover general principles which could claim binding authority. Only in this way was it possible to find on the continent a body of rules entitled to claim universal recognition, an aim which most

\footnotetext{
${ }^{25}$ To the effect that the doctrines should be kept apart, see Arminjon, La Fraude à la Loi en Droit International Privé (I920) 47 Clunet, 409; (I92r) 48 Clunet, 62,4 II.

${ }^{2}$ France, Cass. July 22, I903 (3I Clunet, 355); March 27, I922 (49 Clunet, II5); App. Douai, March 26, 1902 (30 Clunet, 599); Italy, Trib. Civ. Livorno, May 5, 1894 (25 Clunet, 415).

"Beach, Uniform Interstate Enforcement of Vested Rights (IgI8) 27 YALE LAW JOURNAT, 656.

${ }^{23}$ Professor Beale asserts that the common law courts have worked out indigenously a theory of vested rights. Beale, Conflict of Laws (1916) 105.
} 
theoretical writers have had before their eyes. In this country the finding of such general principles must have seemed indispensable, from the standpoint of the writers adopting the a priori mode of reasoning, to prevent confusion in this branch of the law, as might result, it was feared, if each state felt free, within constitutional limitations, to adopt the rules of the Conflict of Laws which its own sense of convenience, justice and policy might suggest. Only in this way can be explained the view that there is a set of fully developed common law principles which are binding upon the courts of the individual states.

The correct mode of approach to this subject would strip it of all fictions and deal with all phenomena $a$ posteriori. ${ }^{39}$ Thus viewed we find that each sovereign state can determine the rules of the Conflict of Laws in accordance with its own notions of what is just and proper, and so far as the individual states of this country are not bound by some constitutional provision, they have the same power. ${ }^{40}$ From the standpoint of the Conflict of Laws all states are primarily interested in the proper administration of justice. Under modern conditions such an administration of justice often demands that a state shall take into consideration the rules of other states. Whether it will do so in a particular situation or not will depend upon the conclusion it reaches as to what is right and proper. In dealing with cases involving foreign elements the court will take into consideration the needs of international trade and the requirements of an increasing intercourse between states and nations. In certain cases, where the operative facts connect the case with some foreign state or country, it will conclude that the promotion of the above ends requires the application of "foreign" law. In other cases, in which the "foreign" law is so far opposed to the local law as to shock the conscience of the court, it will determine the case with reference to the local rule. As justice can be administered only in accordance with the sense of what is right existing in the community in which the court sits, the feelings of the local community cannot be disregarded altogether. The general problem is, therefore, always the same: What are the demands of justice in the particular situation; what is the controlling policy?

If the situation is one admitting of the application of "foreign" law, the choice of the rule to be applied will be determined again in many instances by general social or economic considerations. For example, if the question relates to capacity, a state may conclude that the principal interest involved is the protection of its citizens or of persons domiciled within its territory, wherever they may be. If this be so, it will probably say that the lex patriae or the lex domiciliz governs "capacity." On the other hand, it may conclude that its principal interest in the matter is the

\footnotetext{
${ }^{2}$ See Fink, Die Prinzipien des Internationalen Privatrechts und die Vorbehaltsklausel, supra note 34 , at p. 164 .

${ }^{40}$ International law imposes practically no restraint. See Lorenzen, The Theory of Qualifications and the Conflict of Laws, supra note 17 , at p. 265, $278 \mathrm{ff}$.
} 
security of local transactions. In this event it will say that the lex loci contractus governs capacity. Continental countries, however, have sometimes chosen both points of contact in this case. ${ }^{41}$ According to these the lex patriae governs capacity, but a person under disability according to his personal law, but not according to the lex fori, will not be allowed to set it up against the party contracting with him in the state of the forum.

A similar mode or reasoning would apply if the question related to the validity of a foreign marriage. In this country the courts have come to the conclusion that the place where the marriage is celebrated is the point of contact in which each state is particularly interested, and by way of reciprocity they have deemed it best to apply the same point of view with respect to marriages celebrated abroad. ${ }^{42}$ The English and continental courts, ${ }^{43}$ on the other hand, have reached a different conclusion with respect to "capacity," as to which they have preferred the personal law of the parties (lex domiciliz or lex patriae). Some late English decisions have insisted upon two points of contact with respect to marriages by foreigners in England (the lex domiciliz and the lex loci celebrationis). ${ }^{44}$

Whatever the point or points of contact chosen by the lex fori, special situations may require the application of the local rule. Suppose, for example, that two citizens of the forum go into another state for the purpose of contracting a marriage which they could not enter into under the local law of the forum. In such a case the courts might reach the conclusion that the local interests of the state demand that its law should not be allowed to be evaded by its own citizens and that its local rule should therefore prevail. ${ }^{45}$ In the customary phraseology, it would be said that the general rule would not be enforced on grounds of public policy.

Suppose, again, that a Mohammedan having two wives should attempt to cohabit with both within the limits of the forum. In this case, there would be no doubt that the local rule should have precedence. On the other hand, if a child, born of the second marriage in a country where polygamy is recognized, should claim by descent title to real property situated within the forum, the courts would no doubt recognize that claim. Intermediate situations between the illustrations given might give rise to considerable doubt as to whether in view of the local interests involved the marriage should be regarded as null and void. According

\footnotetext{
"See for example Art. 7, Introductory Law, German Civil Code.

"See Commonzealth v. Lane (1873) II3 Mass. 458.

3 Lorenzen, op. cit. sispra note 6 , at p. 627 , note.

${ }^{4}$ Chetti v. Chetti [rgog] P. 67; Ex parte Mir-Anwartddin [1917, C. A.] I K. B. 634; see Dicey, op. cit. supra note I, at p. 839.

${ }^{45}$ In re Stull's Estate (1898) I83 Pa. 625, 39 Atl. 16; Pennegar v. State (I889) 87 Tenn. 244. Io S. W. 305; Wilson v. Cook (1912) 256 I11. 460 , 100 N. E. 222. Contra: Van Voorhis v. Brininall (188I) 86 N. Y. I8; State v. Shattuck (I897) 69 Vt. 403, 38 Atl. 8I; Dudley v. Dudley (r9II) 15I Iowa, 142, I30 N. W. 785.
} 
to the traditional view it is customary to say that a polygamous marriage will not be recognized on grounds of public policy. Such a statement, however, is inaccurate, for a judge cannot close his eyes to the institution of polygamy in all cases, and it is only when it reaches a certain point of contact with the law of the forum that it can be said to come into real conflict with its social policy. Only in these cases will the judge be justified to regard it as of no effect. ${ }^{46}$

Anglo-American courts, it is submitted, have developed the rules of the Conflict of Laws in the main, though not always consciously, in the manner just outlined. Their aim has been to render a just decision under the circumstances of the particular case and they have reached their conclusions so far as possible by a consideration of the social interests involved. Many rules of the Conflict of Laws, it is true, have been followed without a reconsideration of the matter, because they were established elsewhere and appeared reasonable. The courts whose decisions were followed, having reached their conclusion in the manner above described and the local conditions being similar, there was no need of doing the work over again.

In many situations in the Conflict of Laws, where there are no social or economic considerations of a decisive character, the task of choosing the proper rule becomes extremely difficult. Whether the local rule shall be applied in these cases or some "foreign" rule will have to be determined as best it may in the light of analogy and the experience and practice of other states or nations. In these instances, it matters less what the rule is than that it shall be certain and so far as possible uniform.

So far as the Supreme Court of the United States is empowered to lay down compulsory rules of the Conflict of Laws for the courts of the different states under the "Full Faith and Credit" clause, the "Due Process" clause, etc., of the federal constitution, the individual states are not free to act as they please. The rules are imposed upon them, and in the nature of things the rules are dictated by what the Supreme Court conceives to be the general interest. The particular interests and policies of the different states are submerged in these cases in the general interest of the nation. But so far as the states are free to choose the Conflict of Laws rules they have the power of independent sovereigns who can, and do, determine their rules with reference to their own view of what justice demands.

The method above outlined, which, subject to the constitutional limitations referred to, gives to each state the power to assert in each problem of the Conflict of Laws its own views, seems at first sight less attractive than the method which seeks to derive the rules of the Conflict of Laws from some supra-state authority, be it that of international law, or, so far as the courts of this country and of England are con-

\footnotetext{
${ }^{40}$ See Comments (1923) 32 Yale Law Journal, 47 I.
} 
cerned, that of a "common law" which is binding upon all. It seems to suggest the absence of general rules and to necessitate the commitment of each case to the caprice of the particular judge before whom it may come. A closer study of the problem shows, however, that these fears are unfounded. So far as this country is concerned, it must be remembered that the Anglo-American legal tradition, which directs and controls our legal mode of reasoning, will in the very nature of things prevent our judges from acting in an arbitrary manner within the field of the Conflict of Laws. They will be guided by the experience of other common law states and will depart from their conclusions only if there are substantial reasons for so doing.

No doubt it would be better if there existed a supra-state authority with power to prescribe the rules of the Conflict of Laws. Each state would sacrifice in such event more of its local policies than it is disposed to do to-day, but as an equivalent for such sacrifice it would gain the advantages resulting from greater harmony in the administration of international justice.

By accepting some $a$ priori theory for the solution of the Conflict of Laws, a state is obliged to make a similar sacrifice of its local policies without gaining a corresponding benefit from greater international uniformity, for all a priori views, whether based upon some theory concerning the binding nature of international law or upon some theory concerning the territoriality of law, express only the theory which the particular writer has in mind. There are thus as many theories as there are writers and consequently as much contrariety in the results as before. Notwithstanding the vogue that a priori theories have enjoyed during the last century on the continent, no approach toward uniformity has been attained. There is no reason, therefore, why our courts should give up their traditional way of working out the problems of the Conflict of Laws in favor of any a priori theory which has no support other than that of the person advocating the same. 